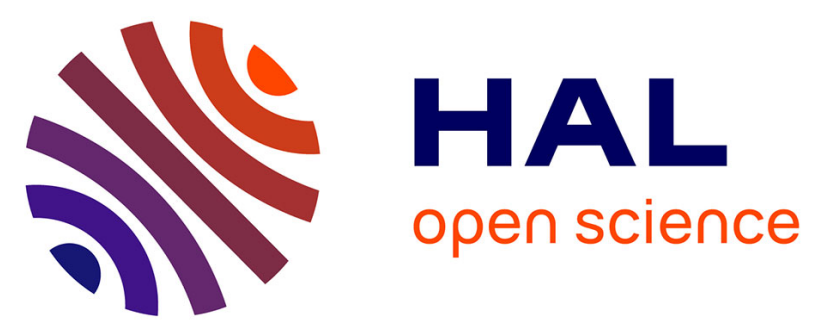

\title{
Low prevalence of zoonotic Babesia in small mammals and Ixodes ricinus in Brittany, France
}

Maggy Jouglin, Grégoire Perez, Alain Butet, Laurence Malandrin, Suzanne Bastian

\section{- To cite this version:}

Maggy Jouglin, Grégoire Perez, Alain Butet, Laurence Malandrin, Suzanne Bastian. Low prevalence of zoonotic Babesia in small mammals and Ixodes ricinus in Brittany, France. Veterinary Parasitology, 2017, 238, pp.58-60. 10.1016/j.vetpar.2017.03.020 . hal-01533216

\section{HAL Id: hal-01533216 https://hal-univ-rennes1.archives-ouvertes.fr/hal-01533216}

Submitted on 5 Jul 2017

HAL is a multi-disciplinary open access archive for the deposit and dissemination of scientific research documents, whether they are published or not. The documents may come from teaching and research institutions in France or abroad, or from public or private research centers.
L'archive ouverte pluridisciplinaire HAL, est destinée au dépôt et à la diffusion de documents scientifiques de niveau recherche, publiés ou non, émanant des établissements d'enseignement et de recherche français ou étrangers, des laboratoires publics ou privés. 
Title: Low prevalence of zoonotic Babesia in small mammals and Ixodes ricinus in Brittany, France.

Authors: M. Jouglin ${ }^{1,2}$, G. Perez ${ }^{1,2,3}$, A. Butet ${ }^{3}$, L. Malandrin ${ }^{1,2}$, S. Bastian ${ }^{1,2}$

1 INRA, UMR1300 Biology, Epidemiology and Risk Analysis in Animal Health, Nantes, France.

2LUNAM Université, Oniris, UMR BioEpAR, Nantes, France.

3UMR CNRS 6553-Université de Rennes 1-ECOBIO, Rennes, France

Correspondence: Suzanne Bastian, UMR1300 Oniris/INRA Biologie Epidemiologie et Analyse de Risques, Atlanpole la Chantrerie, CS 40706, 44307 Nantes cedex (France). suzanne.bastian@onirisnantes.fr 


\section{Highlights}

- Prevalences of Babesia spp. were investigated in small mammals and Ixodes ricinus.

- Only one Bank vole carried B. microti and 13 ticks carried B. venatorum.

- Exposure of humans to zoonotic Babesia is probably low in western France.

\section{Summary}

In order to evaluate the zoonotic risk due to Babesia spp., especially $B$. microti, we investigated their presence in 597 individuals of five small mammal species and in 2620 questing nymphs of Ixodes ricinus in rural landscapes of Western France (Brittany). Small mammals (rodents and shrews) are indeed suspected to be reservoir hosts for B. microti, and the tick I. ricinus is the vector of the three main zoonotic species in Europe, i.e. B. divergens, $B$. venatorum and B. microti. Only one bank vole carried B. microti (genotype "Munich") and only 13 and 2 nymphs of Ixodes ricinus ticks carried $B$. venatorum and $B$. capreoli respectively. According to these results, prevalences observed for zoonotic Babesia $(0.17 \%$ for small mammals and $0.50 \%$ for ticks), indicate that exposure of humans to this infectious agent is probably low in western France.

Keywords: Babesia; Babesia microti; Ixodes ricinus; Zoonoses; Disease Reservoirs; Disease vectors. 


\section{Introduction}

Emergence or re-emergence of tick-borne diseases is likely to be induced by land use changes and their consequences on the communities of vertebrate reservoirs and vectors (Lambin et al., 2010). Three species of Babesia of concern for human health are transmitted by Ixodid ticks in the Northern hemisphere: B. microti, B. divergens and B. venatorum (Babesia sp. EU1) (Gray et al., 2010; Schnittger et al., 2012). Transmitted by Ixodes scapularis ticks in Northern America, $B$. microti has been incriminated as an etiological agent in hundreds of cases, often in immunocompetent individuals. In Eurasia, autochthonous human cases are more rarely reported, and attributed to $B$. divergens or $B$. venatorum, but not to $B$. microti despite its presence on this continent. Both species cause mild to deadly babesiosis on splenectomized or otherwise immunocompromised patients, and both are transmitted by I. ricinus ticks. Their vertebrate reservoirs are mainly domestic cattle and roe deer (Capreolus capreolus) (Devos and Geysen, 2004; Bastian et al., 2012). Adult females of I. ricinus acquire the parasites during blood meal and transmit them first transovarially to, and then transtadially within the next tick generation. Conversely, B. microti, also detected in vertebrate hosts and I. ricinus in Europe, is unable to be passed down transovarially. This infection is therefore acquired mainly by larvae feeding on infected small mammals, its main vertebrate reservoir (Gray et al., 2010). The predominant transmitter to humans of the three zoonotic Babesia species in Western Europe is therefore the nymphal stage of I. ricinus.

\section{Material and methods}

In a project (OSCAR) designed to study the exposure to infected I. ricinus ticks in rural landscapes, we sampled small mammals and questing I. ricinus nymphs in the "Zone Atelier Armorique" (https://osur.univ-rennes1.fr/za-armorique/) a Long Term Ecological Research (LTER) area located North-East of the Brittany region, France $\left(48^{\circ} 30^{\prime} \mathrm{N}, 1^{\circ} 32^{\prime} \mathrm{W}\right)$. Small mammals were trapped at 24 different locations ( 6 in core forest, 6 at forest edges and 12 at meadow/wood or meadow/hedgerow ecotones). Trapping sessions were carried out in May-June and October in 2012 
and 2013. For each location, we set up linear trap lines of 34 baited live-traps spaced every 3 meters, checked after 24 and $48 \mathrm{~h}$, for a total of 1632 trap nights each season. Ticks were sampled by the dragging method along 100 -square metre transect subdivised in ten 10 -square metre subtransects (see Perez et al, 2016 for more details). The sampling sites, 24 for both small mammals and ticks, and 36 additional sites for only ticks, were located either in forest habitats or at woodland-grassland ecotones in various landscape contexts (ratio crops/grasslands, hedgerow network density). These ecotones are the most favorable habitats for I. ricinus and the maintenance of vector-host cycles. We described the prevalence of Babesia, at the species and strain levels, by detecting and sequencing a hypervariable region of the Babesia $18 \mathrm{~S}$ rRNA gene in I. ricinus nymphs and in rodents. This marker allows discrimination of numerous Babesia species (Gray et al., 2010; Schnittger et al., 2012).

Small mammals were trapped in May-June and October in 2012 and 2013. They were euthanized by authorized experimenters (pentobarbital injection) in accordance with French law, dissected and their spleen removed to be stored at $-20^{\circ} \mathrm{C}$ until further analysis. A total of 597 animals have been tested, including 441 Apodemus sylvaticus, 147 Myodes glareolus, 4 Microtus agrestis, 2 Microtus subterraneus and 3 Sorex coronatus. Questing nymphs were collected by dragging the vegetation with a white flannel blanket in spring 2012 and 2013. Ticks removed from the blanket were conserved in ethanol $70 \%$ and identified under a binocular microscope according to Pérez-Eid (Pérez-Eid, 2007). A total of 2620 I. ricinus nymphs were screened for Babesia spp.

Genomic DNA was extracted from individual ticks using ammoniac lysis (Morán-Cadenas et al., 2007), and from spleen tissue using the kit Macherey NucleoSpin Tissue (Macherey Nagel, Germany). The detection of Babesia spp. and B. microti was achieved by nested PCR of the $18 \mathrm{~S}$ rRNA gene. Different primers were used to amplify Babesia spp. from ticks and B. microti from small mammals, as we experienced false positive amplifications with generic primers on small mammal spleen extracts (Table 1) (Persing et al 1992; Welc-Falęciak et al., 2007; Malandrin et al., 2010). The PCR conditions were: final volume $30 \mu$ l containing $0.33 \mathrm{mM}$ dNTPs (Eurobio, France), 
$1 \mathrm{X}$ PCR buffer, $1 \mathrm{U}$ Extaq Takara (Ozyme, France), $1 \mu \mathrm{M}$ each primer and deionized water. In a separate room, $7 \mu \mathrm{l}$ of DNA extract were added. PCR steps: $98^{\circ} \mathrm{C} 5 \mathrm{~min}-40$ cycles of $\left(98^{\circ} \mathrm{C} 30 \mathrm{~s}\right.$, selected annealing temperature $30 \mathrm{~s}, 72^{\circ} \mathrm{C} 30 \mathrm{~s}$ ) - final elongation $72^{\circ} \mathrm{C} 5 \mathrm{~min}$. A sample of $10 \mu \mathrm{l}$ amplicons (diluted 1:100) of the first PCR step was used as template for the nested PCR. Genomic DNA from Theileria ovis (accession number: FJ603460) and B. microti (reference sequence XR_001160982.1 strain R1) were used as positive controls. Positive amplicons were purified using ExoSAP-IT (Ozyme, France) and sent for Sanger conventional sequencing (GATC, Germany). Sequences were assigned to species using BLASTn identity searches in GenBank and a detailed analysis of nucleotide substitutions with reference sequences.

\section{Results and discussion}

We found a low prevalence of infection by Babesia species in rodents and in questing $I$. ricinus nymphs (Table 2). Three species were detected, B. microti in rodents, $B$. venatorum and $B$. capreoli in ticks. The latter is non-zoonotic, closely related to, but different from, the zoonotic $B$. divergens (Gray et al., 2010; Malandrin el al., 2010). Roe deer is the vertebrate reservoir of both $B$. venatorum and B. capreoli, and an important blood source for adult $I$. ricinus, who acquire these parasites and transmit them transovarially. Their detection in questing nymphs in such a biotope frequented by roe deer could therefore be expected. The zoonotic $B$. divergens was not detected in nymphs despite the occurrence of sporadic babesiosis in cattle in the area.

B. microti was detected only in the spleen of one Myodes glareolus in autumn 2012 in a forest habitat (Table 2). This sequence (Genbank accession number KX758442) was of type "Munich", which has only once been suggested to be the cause of a case of low grade human babesiosis (Arsuaga et al., 2016). Recent phylogenetic work on B. microti discriminated 4 lineages ("USA-type" also called "Gray", "Munich", "Kobe” and "Hobetsu”) (Schnittger et al., 2012). Only the North-American variants of the USA-type are known to be associated with frequent detrimental outcomes in humans, to the point that it has become a nationally notifiable condition in the USA. In 
Europe, the only reported severe case of autochthonous B. microti involved the USA-type, and transfusion was the most probable source of infection (Hildebrandt et al., 2007).

Rodent and shrew reservoir species for B. microti (Apodemus spp., Microtus spp., Myodes spp., Sorex spp.) are highly dependent on the biotope and have apparently variable reservoir efficiency (Welc-Falęciak et al., 2008). Microtus species are considered as the main B. microti reservoir in Europe, but they prefer open habitats and were underrepresented in our study focused on ecotones ( $1.0 \%$ of the rodents), although they reach $9.5 \%$ to $28.2 \%$ in barn owl pellets in agricultural landscapes of this region (Groupe Mammalogique Breton, 2015). In North-East Poland, B. microti (USA-type) prevalence in small mammals can reach $35 \%$ in Microtus arvalis in fallow land landscapes (Welc-Falęciak et al., 2008), but small mammal and tick communities are quite different between Western and Eastern Europe (Atlantic versus Continental biogeographical area). It has been shown that I. trianguliceps (with all 3 developmental stages feeding on small mammals) is the main vector for $B$. microti, while $I$. ricinus (with larvae feeding on rodents and nymphs and adults on larger vertebrates) would only serve as a bridge vector (Bown et al., 2008). So, although at least one B. microti variant may be enzootic in rodents in Western France, its apparent absence in $I$. ricinus in our study leads to think that human exposure to zoonotic Babesia in this area is very low. Combined serological and PCR screening of blood donors may give a more accurate estimation of exposure to contamination by tick bites, and may help to assess risks for transfusion patients.

\section{Acknowledgements}

Maggy Jouglin and Grégoire Perez contributed equally to this manuscript. We thank the members of

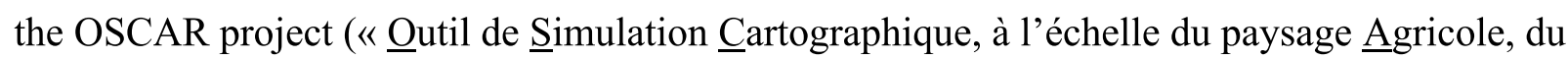
Risque acarologique » Grant of the French National Research Agency ANR-11-Agro-001-04; Call for Proposal 'Agrobiosphere') coordinated by Olivier Plantard, for participation in the field and laboratory work, in particular the INRA EpiA research unit for the database setup and maintenance, and Amélie Chastagner, for providing the small mammal spleen DNA samples. Grégoire Perez was 
supported by a PhD fellowship from the region of Brittany. Thanks to Bernard Carcy for providing positive control B. microti DNA, as well as to Sam R. Telford III for DNA used in setup experiments. We thank the REID-TMT working group on ticks and tick-borne diseases for helpful discussions.

\section{References}

Arsuaga, M., L. M. Gonzalez, C. A. Lobo, F. de la Calle, J. M. Bautista, I. G. Azcárate, S. Puente, E. Montero, 2016. First report of Babesia microti-caused babesiosis in Spain. Vector Borne Zoonotic Dis. 16, 677-679.

Bastian, S., M. Jouglin, N. Brisseau, L. Malandrin, G. Klegou, M. L’Hostis, A. Chauvin, 2012. Antibody prevalence and molecular identification of Babesia spp. in roe deer in France. $J$. Wildl. Dis. 48, 416-424.

Bown, K. J., X. Lambin, G. R. Telford, N. H. Ogden, S. Telfer, Z. Woldehiwet, R. J. Birtles, 2008. Relative importance of Ixodes ricinus and Ixodes trianguliceps as vectors for Anaplasma phagocytophilum and Babesia microti in field vole (Microtus agrestis) populations. Appl. Environ. Microbiol. 74, 7118-7125.

Devos, J., D. Geysen, 2004. Epidemiological study of the prevalence of Babesia divergens in a veterinary practice in the mid-east of France. Vet. Parasitol. 125, 237-249.

Gray, J., A. Zintl, A. Hildebrandt, K. P. Hunfeld, L. Weiss, 2010. Zoonotic babesiosis: overview of the disease and novel aspects of pathogen identity. Ticks Tick Borne Dis. 1, 3-10.

Groupe Mammalogique Breton, 2015. Atlas des mammifères de Bretagne. Simonnet F, ed. Lopérec: Locus Solus. ISBN 978-2368330920

Hildebrandt, A., K. P. Hunfeld, M. Baier, A. Krumbholz, S. Sachse, T. Lorenzen, M. Kiehntopf, H. J. Fricke, E. Straube, 2007. First confirmed autochthonous case of human Babesia microti 
infection in Europe. Eur. J. Clin. Microbiol. Infect. Dis. 26, 595-601.

Lambin, E. F., A. Tran, S. O. Vanwambeke, C. Linard, V. Soti, 2010. Pathogenic landscapes: interactions between land, people, disease vectors, and their animal hosts. Int. J. Health Geogr. 9, 54.

Malandrin, L., M. Jouglin, Y. Sun, N. Brisseau, A. Chauvin, 2010. Redescription of Babesia capreoli (Enigk and Friedhoff, 1962) from roe deer (Capreolus capreolus): isolation, cultivation, host specificity, molecular characterisation and differentiation from Babesia divergens. Int. J. Parasitol. 40, 277-284.

Morán-Cadenas, F., H. Schneider, E. Lommano, C. Burri, J. Moret, L. Gern, 2007. A comparison of two DNA extraction approaches in the detection of Borrelia burgdorferi sensu lato from live Ixodes ricinus ticks by PCR and Reverse Line Blotting. Vector-Borne Zoonotic Dis. 7, 555562.

Perez, G., S. Bastian, A. Agoulon, A. Bouju-Albert, A. Durand, F. Faille, I. Lebert, Y. Rantier, O. Plantard, and A. Butet. 2016. Effect of landscape features on the relationship between Ixodes ricinus ticks and their small mammal hosts. Parasites \& Vectors 9, 1-18.

Pérez-Eid, C. 2007. Les tiques : Identification, biologie, importance médicale et vétérinaire, Lavoisier, Paris.

Persing, D. H., D. Mathiesen, W. F. Marshall, S. R. Telford, A. Spielman, J. W. Thomford, P. A. Conrad, 1992. Detection of Babesia microti by polymerase chain reaction. J. Clin. Microbiol. $30,2097-2103$.

Schnittger, L., A. E. Rodriguez, M. Florin-Christensen, D. A. Morrison, 2012. Babesia: a world emerging. Infect. Genet. Evol.12, 1788-1809.

Welc-Falęciak, R., A. Bajer, M. Bednarska, A. Paziewska, E. Siński, 2007. Long term monitoring of 
Babesia microti infection in BALB/c mice using nested PCR. Ann. Agric. Environ. Med. 14, $287-290$.

Welc-Falęciak, R., A. Bajer, J. M. Behnke, E. Siński, 2008. Effects of host diversity and the community composition of hard ticks (Ixodidae) on Babesia microti infection. Int. J. Med. Microbiol. 298, 235-242.

\section{List of tables}

Table 1. PCR amplification conditions for Babesia spp. detection.

Table 2. Babesia spp. detection in small mammals and ticks. Results of PCR and sequencing of Babesia spp. 18S rRNA gene amplified from 597 small mammals and 2620 questing I. ricinus nymphs sampled in rural landscapes in 2012 and 2013 in North-eastern Brittany, France. 
Table 1. PCR amplification conditions for Babesia spp. detection

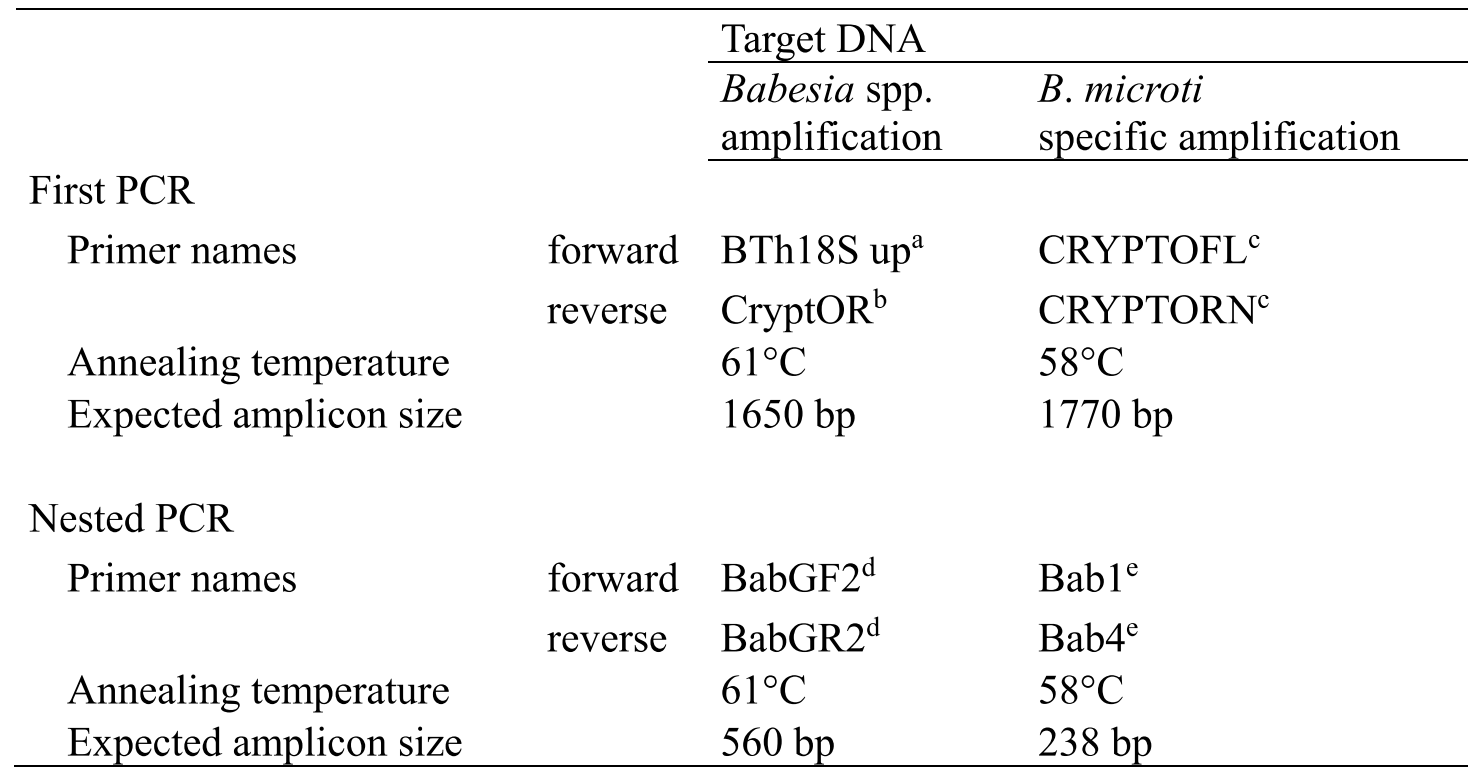

a 5'- GGG CTA ATA CAW GTT CGA G- 3' this study, b 5' - GAA TGA TCC TTC TGC AGG TTC

ACC TAC - 3' this study, ${ }^{\mathrm{c}}$ (Welc-Falęciak et al., 2007), ' (Malandrin et al., 2010), ${ }^{\mathrm{e}}$ (Persing et al., 1992)

Table 2. Babesia spp. detection in small mammals and ticks. Results of PCR and sequencing of Babesia spp. 18S rRNA gene amplified from 597 small mammals and 2620 questing I. ricinus nymphs sampled in rural landscapes in 2012 and 2013 in North-eastern Brittany, France.

\begin{tabular}{lll}
\hline & \multicolumn{2}{l}{ Positive/tested } \\
\cline { 2 - 3 } Year & 2012 & 2013 \\
\cline { 2 - 3 } Small mammals & $0 / 208$ & \\
B. microti (spring) & $1 / 283$ & $0 / 30$ \\
B. microti (autumn) & $0 / 76$ \\
Questing I. ricinus nymphs (spring) & \\
B. microti & $0 / 1215$ & $0 / 1405$ \\
B. venatorum & $8 / 1215$ & $5 / 1405$ \\
B. capreoli & $0 / 1215$ & $2 / 1405$ \\
\hline
\end{tabular}

